\title{
Structure and expression of two nuclear receptor genes in marsupials: insights into the evolution of the antisense overlap between the $\alpha$-thyroid hormone receptor and Rev-erbo
}

\author{
Brandon C Rindfleisch ${ }^{1,2 \dagger}$, M Scott Brown ${ }^{1,3+}$, John L VandeBerg ${ }^{4}$, Stephen H Munroe ${ }^{1 *}$
}

\begin{abstract}
Background: Alternative processing of $\alpha$-thyroid hormone receptor (TR $\alpha, N R 1 A 1)$ mRNAs gives rise to two functionally antagonistic nuclear receptors: TR $\alpha$ 1, the $\alpha$-type receptor, and TR $\alpha 2$, a non-hormone binding variant that is found only in mammals. TR 22 shares an unusual antisense coding overlap with mRNA for Rev-erb $\alpha$ (NR1D1), another nuclear receptor protein. In this study we examine the structure and expression of these genes in the gray short-tailed opossum, Monodelphis domestica, in comparison with that of eutherian mammals and three other marsupial species, Didelphis virginiana, Potorous tridactylus and Macropus eugenii, in order to understand the evolution and regulatory role of this antisense overlap.

Results: The sequence, expression and genomic organization of mRNAs encoding TR $\alpha 1$ and Rev-erb $\alpha$ are very similar in the opossum and eutherian mammals. However, the sequence corresponding to the TRa 2 coding region appears truncated by almost 100 amino acids. While expression of TRo 1 and Rev-erbo was readily detected in all tissues of $M$. domestica ages 0 days to 18 weeks, TR $\alpha 2$ mRNA was not detected in any tissue or stage examined. These results contrast with the widespread and abundant expression of TR 22 in rodents and other eutherian mammals. To examine requirements for alternative splicing of TRa mRNAs, a series of chimeric minigenes was constructed. Results show that the opossum TRa2-specific $5^{\prime}$ splice site sequence is fully competent for splicing but the sequence homologous to the TR $223^{\prime}$ splice site is not, even though the marsupial sequences are remarkably similar to core splice site elements in rat.

Conclusions: Our results strongly suggest that the variant nuclear receptor isoform, TR $\alpha 2$, is not expressed in marsupials and that the antisense overlap between TR $\alpha$ and Rev-erb $\alpha$ thus is unique to eutherian mammals. Further investigation of the TR $\alpha$ and Rev-erb $\alpha$ genes in marsupial and eutherian species promises to yield additional insight into the physiological function of TR $\alpha 2$ and the role of the associated antisense overlap with Rev-erbo in regulating expression of these genes.
\end{abstract}

\section{Background}

Recent genome-wide studies have revealed far more extensive transcription of mammalian genomes than previously recognized [1-6]. One consequence of this pervasive transcription is the occurrence of widespread bidirectional transcription that results in overlapping

\footnotetext{
* Correspondence: munroes@marquette.edu

† Contributed equally

'Department of Biological Sciences, Marquette University, Milwaukee, WI, USA

Full list of author information is available at the end of the article
}

transcripts antisense to most known mRNAs [5,7-9]. Such antisense transcription takes several forms. Both long and short non-coding antisense transcripts have been described overlapping either the 5' or 3' ends of mRNAs. In other instances two mRNAs encoded on opposite strands share such an overlap. Although regulatory implications of antisense transcription are unclear, many studies suggest that the mechanisms associated with expression of antisense RNA in eukaryotes are remarkably diverse and mechanistically complex [9-14]. 
One of the first examples of an antisense overlap between two mRNAs involves two nuclear receptor genes, the $\alpha$-type thyroid hormone receptor gene (TR $\alpha$; also NR1A1 or THRA) and the Rev-erb $\alpha$ gene (NR1D1) [15-17]. These genes share an antisense overlap that reflects the presence of a novel alternatively spliced mRNA that is highly conserved in most mammals but is absent in non-mammalian vertebrates [18]. Alternative processing of TR $\alpha$ pre-mRNAs yields two functionally distinct proteins. One is the canonical thyroid hormone (T3) receptor, TR $\alpha 1$, that activates target genes in a thyroid hormone (T3)-dependent manner. The other, $\mathrm{TR} \alpha 2$, has a novel C-terminal sequence encoded by an exon antisense to Rev-erb $\alpha$. TR $\alpha 2$ mRNA lacks both the hormone-binding domain and a critical activation domain present in TR $\alpha 1$ and may function as a weak dominant negative repressor, repressing expression of genes activated by TR $\alpha 1$ in the presence of T3 [17]. Rev-erb $\alpha$ has a DNA-binding specificity distinct from $\mathrm{TR} \alpha 1$ and $\mathrm{TR} \alpha 2$. Like TR $\alpha 1$, Rev-erb $\alpha$ possesses a canonical ligand binding domain but, like TR $\alpha 2$, it lacks the AF-2 activation domain. Thus, both Rev-erb $\alpha$ and $\mathrm{TR} \alpha 2$ are constitutive repressors, although they bind distinct sets of target genes.

$\mathrm{TR} \alpha 1$ and Rev-erb $\alpha$ play important roles in metabolic and developmental regulation [19-21]. TR $\alpha 1$ mediates T3 activity critical for vertebrate development and homeostatic metabolism. Rev-erb $\alpha$ plays critical roles in adipogenesis and lipid metabolism, while occupying a specific node in the mammalian circadian clock [22-26]. While previously considered a ligandless orphan receptor, Rev-erbo has recently been shown to bind heme specifically within its canonical ligand binding domain (LBD) $[24,26]$. Interactions of Rev-erbo with its corepressors are enhanced in the presence of heme and, with heme bound, may respond to physiological regulators such as nitric oxide $[23,27,28]$. Thus, Rev-erb $\alpha$ has emerged as an important integrator of inputs from multiple physiologic pathways [29-31].

The overlap architecture of the region encoding TR $\alpha$ and Rev-erb $\alpha$ (here referred to as the TR $\alpha / R e v$-erb $\alpha$ locus) and the physiological importance of these nuclear receptors raise important questions relating to the function, evolution and regulation of this locus. The evolutionary constraints imposed on such a bidirectional coding sequence argue that it is highly unlikely that such an overlap would occur without some functional benefit. Several lines of evidence support the hypothesis that expression of Rev-erb $\alpha$ mRNA may affect the balance between TR $\alpha 1$ and TR $\alpha 2$ through inhibition of TR $\alpha 2$ splicing [32-35]; however, such an interaction has not been demonstrated under physiological conditions.

In this study we first analyze the structure of the $\mathrm{TR} \alpha /$ Rev-erb $\alpha$ locus in Monodelphis domestica, the gray short-tailed opossum, the first published marsupial genome [36], and compare it with that of other marsupials. Individually, $\mathrm{TR} \alpha$ and Rev-erb $\alpha$ genes and transcripts are highly conserved in the opossum in comparison with those of eutherian mammals. However, the region corresponding to the Rev-erb $\alpha / T R \alpha 2$ overlap in eutherian mammals displays several divergent features. Most of the C-terminal coding sequence unique to TR $\alpha 2$ is missing in $M$. domestica due to the introduction of an in-frame stop codon that eliminates the bidirectional coding overlap with Rev-erb $\alpha$. Furthermore, expression of TR $\alpha 2$ mRNA was not detected in the opossum in any of a variety of tissues or developmental stages. These results are surprising given the remarkable conservation of TR 2 and its abundant and developmentally regulated expression in eutherian mammals. Analysis of chimeric minigenes comprised of opossum and rat sequences demonstrated that opossum sequences homologous to the TR $\alpha 2$-specific splice site (3'ss) are very poorly utilized in comparison with similar rat minigenes. These studies thus document the evolution of a novel alternatively spliced exon in mammals and the creation of antisense overlap between two important regulatory proteins.

\section{Results}

\section{Structures of eutherian TR $\alpha 1$ and Rev-erb $\alpha$ mRNAs are} conserved in marsupials

Inspection of the genome of Monodelphis domestica [36] reveals a single locus on chromosome 2 in which the $\mathrm{TR} \alpha$ and Rev-erb $\alpha$ genes are arrayed in a convergent orientation similar to that in rat and other mammalian genomes (Figure 1). The coding regions for TR $\alpha 1$ (additional file 1 Panel A) and Rev-erb $\alpha$ are separated by only $3.85 \mathrm{~kb}$, similar to the close spacing of the coding regions in the rat genome $(3.71 \mathrm{~kb})$. Furthermore, the non-coding sequence extending across and between the 3 ' ends of these genes is also very well conserved (Figure 1B). The most striking conservation is located at the extreme 3' end of TR $\alpha 1 \mathrm{mRNA}$, in which a sequence of $140 \mathrm{bp}$ is almost identical to that in the rat and other eutherian mammals. The region surrounding the 3 ' end of Rev-erbo is also highly conserved and is flanked upstream and downstream by homopolymeric runs of 3 or more $\mathrm{C}\left(\mathrm{C}\right.$-rich or $\mathrm{C}_{\mathrm{n}}$ ) and $\mathrm{G}\left(\mathrm{G}\right.$-rich or $\mathrm{G}_{\mathrm{n}}$ ) residues, respectively, as is the case in other mammals (Figure $1 \mathrm{~B}$ and additional file 2).

Closer inspection of the sequence for $M$. domestica $\mathrm{TR} \alpha$, however, reveals that the first coding exon of TR $\alpha 1$ mRNA is entirely missing in the genome assembly due to a $5 \mathrm{~kb}$ gap [36]. Also, apparent sequencing errors at positions 54 and 124 of exon 6 disrupt the reading frame for $T R \alpha 1$ by introducing, respectively, a one-base insertion and a stop codon. The complete 


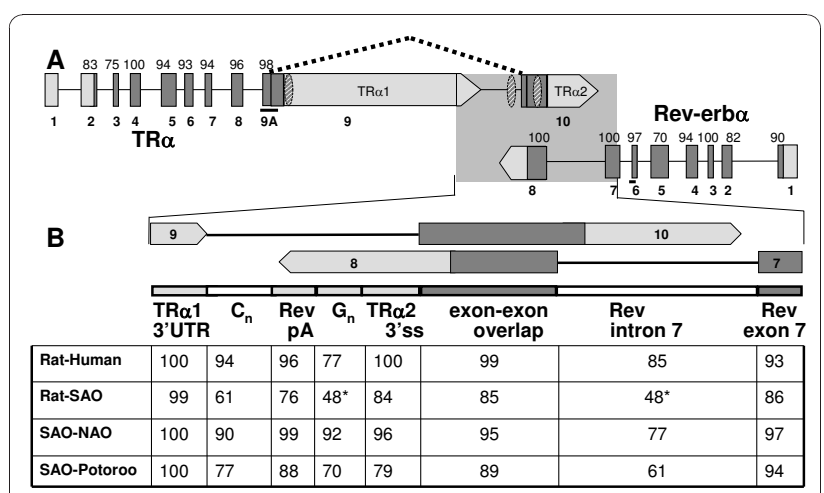

Figure 1 The TR $\alpha /$ Rev-erb $\alpha$ locus is conserved in marsupials. A. Structure of TR $\alpha$ and Rev-erb $\alpha$ genes is shown schematically for rat and $M$. domestica. Rectangular boxes indicate exons, boxes terminating in arrows represent poly(A) sites, dark shading indicates coding sequences and bold vertical lines the alternative 5 'ss splice site for exon 9A and stop codons for TR $\alpha 1$ (exon 9) and TR $\alpha 2$ (exon 10). Alternative splicing of $T R \alpha 2$ (exon $9 A$ to exon 10) is indicated by dotted angle line. Percent amino acid identity is indicated above each exon and exon numbering is shown in bold below. Conservation of TR 22 exon 10 is described in Figure 2. Probes for RNase protection assays are indicated by bold lines under TR $\alpha$ exon 9A and Rev-erba exon 6. Hatched ellipses indicate positions of elements that enhance TRo2 mRNA splicing [38]. B. (top) To-scale enlargement of the antisense overlap showing portions of exons from TR $\alpha 1, T R \alpha 2$ and Rev-erb $\alpha$ mRNAs within shaded region in panel A. Shaded horizontal bar indicates eight subregions based on an alignment of eutherian and marsupial sequences across this region (additional file 2). $C_{n}$ and $G_{n}$ represent regions that include multiple runs of $C$ and $G$ residues, respectively. Rev $p A$ is the conserved region centered on the Rev-erba poly(A) site. Table at bottom shows percent identity for selected pairwise comparsions: $\mathrm{SAO}$, South American opossum (M. domestica); NAO, North American opossum (D. viriginiana); potoroo, P. tridactylus. Asterisks indicate highly gapped regions in the alignment.

coding sequence for $M$. domestica TR $\alpha 1$ was obtained by sequencing cDNA using primers complementary to conserved sequences in the 5' UTR and at intervals throughout the coding sequence. The TR $\alpha 1$ coding sequence for $M$. domestica from this analysis was identical in all other respects to the current genome assembly (additional file 1 Panel A). As shown in Figure 1 the amino acid sequence of opossum TR $\alpha 1$ is closely similar to that of rat, with $93 \%$ identity at the amino acid level. Rev-erb $\alpha$ is also well conserved with $84 \%$ identity. The 3 ' ends of TR $\alpha 1$ and Rev-erb $\alpha$ mRNAs from opossum were mapped via RNase protection assays and 3' RACE, respectively (results not shown), and were found to coincide precisely with the sites previously reported for rat $[15,32]$ as indicated in additional file 2 . To confirm these observations, mRNA sequences for $\mathrm{TR} \alpha 1$ and Rev-erb $\alpha$ were determined for a second marsupial, Potorous tridactylus (the long-nosed potoroo). The opossum and potoroo amino acid sequences, representing the two largest marsupial orders, Didelphia and
Diprotodontia, about 80 My diverged [37], are very similar: 99\% and 96\% identity for TR $\alpha 1$ and Rev-erb $\alpha$, respectively (additional file 1 ).

In contrast to the strong conservation of $T R \alpha 1$ and Rev-erb $\alpha$, sequences corresponding to the alternatively spliced exon 10 of TR 2 mRNA display a puzzling mix of conserved and non-conserved features. Sequences corresponding to the core 3'ss elements for this exon are nearly identical in rat and $M$. domestica, including the intronic polypyrimidine tract and the non-consensus AAG immediately preceding the 3 'ss (Figure $2 \mathrm{~B}$ and additional file 2). Sequence at the 5 ' end of exon 10, corresponding to 11 codons in rat TR $\alpha 2$, is also well conserved but at that point the similarity between marsupial and eutherian sequence ends abruptly until reaching the coding sequence for Rev-erb $\alpha$. The divergent region includes a 12 nucleotide insertion in opossum and an inframe stop codon immediately preceding the stop codon for Rev-erb $\alpha$ on the strand antisense to TR $\alpha$. These adjacent stop codons, present in both species of opossum but absent in wallaby and potoroo, as described below, precisely eliminate the bidirectional coding overlap between $\mathrm{TR} \alpha 2$ and Rev-erbo mRNAs seen in rat and other eutherian mammals [17,38]. Finally, the Rev-erb $\alpha$ amino acid sequence encoded by its terminal exon is identical in opossum and rat. However, there are 26 synonymous substitutions in Rev-erbo sequence, almost all of which alter the coding potential of the TR $\alpha$ strand in opossum.

To further explore the significance of this sequence comparison, we examined $1.5 \mathrm{~kb}$ of genomic sequence that span the 3' end of TR $\alpha 1$ and extend across exon 8 and part of exon 7 of Rev-erbo in three other marsupial species: Didelphis virginiana (the Virginia opossum), P. tridactylus, and Macropus eugenii (the tammar wallaby). Alignment of all four marsupial sequences with those of rat shows a high level of conservation of marsupial features similar to that shown in Figure 1B and additional file 2. As expected, since both are of the order Didelphimorphia, the sequence of the opossum $D$. virginiana is very similar to that of $M$. domestica ( $89 \%$ identity across mostly non-coding sequence). Both include a 12-nucleotide insertion and in-frame stop codon in the region adjacent to the stop codon for Reverb $\alpha$ (Figure 2B). Sequences for wallaby and potoroo (both of the order Diprotodontia) are similar to those from the opossums in the region homologous to exon 10 of TR $\alpha 2$. Furthermore, the amino acid sequences encoded by the 3' exon of Rev-erbo in all four marsupials are identical to that of rat except for a single residue change in the potoroo, although each sequence contains many substitutions which are silent with respect to Rev-erba (Figure $2 \mathrm{C}$ ).

Despite their high degree of similarity overall, the potoroo and wallaby sequences differ from those of the 


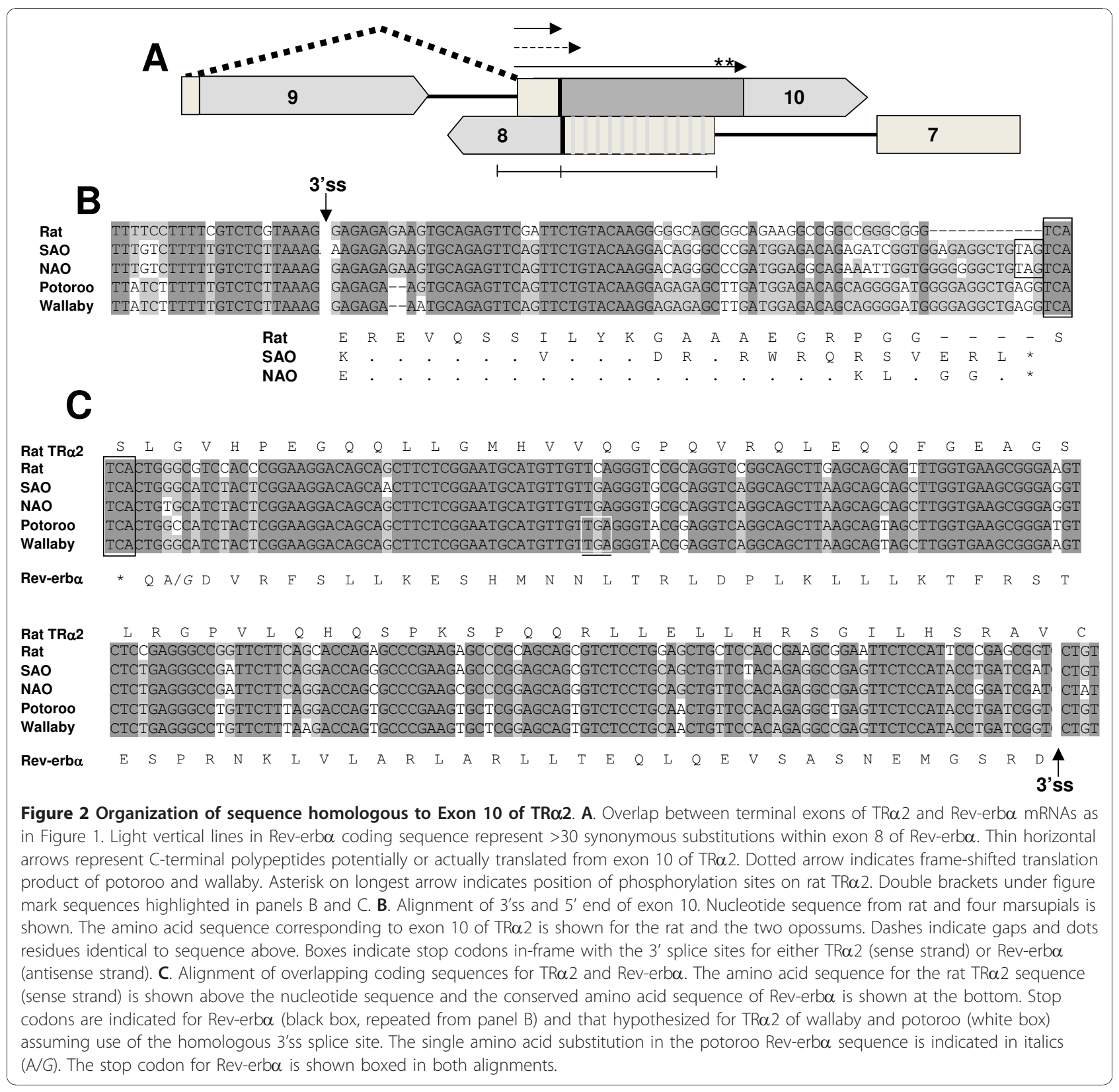

opossums in one notable respect: there is a two-basepair deletion immediately downstream of sequences homologous to the 3'ss of exon 10 in TR $\alpha 2$ mRNA. This deletion disrupts the reading frame corresponding to the $\mathrm{C}$-terminus of TR $\alpha 2$ and creates a novel open reading frame that extends past the Rev-erb $\alpha$ stop codon, overlapping the Rev-erb $\alpha$ coding region by 16 codons (Figure 2B and 2C).

\section{Expression of TR $\alpha$ and Rev-erb $\alpha$ mRNAs in marsupials}

Given the conservation of so many features within the $\mathrm{TR} \alpha / \operatorname{Rev}$-erb $\alpha$ locus in marsupials, it seemed likely that marsupials might express an alternatively spliced mRNA yielding a truncated version of $\mathrm{TR} \alpha 2$. To characterize expression of mRNAs from Rev-erb $\alpha$ and $\mathrm{TR} \alpha$ genes we examined RNA from multiple tissues from $M$. domestica at six different ages ranging from newborn animals (0 days) to weanlings ( 9 weeks) and young adults (18 weeks).

Expression of both TR $\alpha 1$ and Rev-erb $\alpha$ mRNAs was readily detected at all stages by RT-PCR. Since newborn and one-week animals are only $10 \mathrm{~mm}$ and $16 \mathrm{~mm}$ in length, respectively, these animals were simply divided into two parts, heads and bodies, for extraction of RNA. Beginning with two-week animals, six different tissues were collected: cerebral cortex, cerebellum, liver, kidney, 
skeletal muscle and heart. For each tissue at each stage, both $\mathrm{TR} \alpha 1$ and Rev-erb $\alpha$ expression were readily detected by realtime RT-PCR and expression of both mRNAs was confirmed by sequencing PCR amplification products. Results of these assays are summarized in Figure $3 \mathrm{~A}$ for heads and bodies of newborn ( 0 or 1 week), and cerebral cortex and livers of older animals (2-18 weeks). Similar results are shown for four other tissues in additional file 3. Increasing expression of Rev-erba correlates strongly with increasing age (with a linear correlation coefficient, $\mathrm{r}>0.95$ in skeletal muscle, kidney, cerebellum and liver, and $r>0.74$ in brain and heart). The highest levels of Rev-erb $\alpha$ expression were observed in liver and skeletal muscle; the lowest levels were in heart. In all tissues except liver Rev-erba showed a large, 4- to 6-fold increase in expression between 4 and 9 weeks $(\mathrm{p}<0.001)$. In fact, TR $\alpha 1$ expression also showed a strong, if less pronounced, correlation with increasing age in all tissues except heart $(\mathrm{r} \geq 0.95$ for $\mathrm{TR} \alpha 1$ in kidney and cerebellum and $\mathrm{r} \geq$ 0.74 in brain, muscle and liver) (additional file 3).

In contrast to TR $\alpha 1$ and Rev-erb $\alpha$ mRNA expression, both realtime and conventional RT-PCR assays for TR $\alpha 2$ were consistently negative. To confirm this result, multiple pairs of primers were tested, including forward primers in exons 7, 8 and 9 and reverse primers annealing to different sites within the region homologous to TR $\alpha 2$ exon 10 and Rev-erb $\alpha$ exon 8. While the threshold values obtained for TR $\alpha 1$ were highly reproducible, typically varying by $<0.2$ cycles for a given set of replicas, replica samples run with primers for TR 22 were highly variable, either displaying large threshold values or altogether failing to cross the threshold. Melt-curves (not shown) and gel electrophoresis of these products revealed a heterogeneous array of non-specific products, as illustrated in the replica lanes shown in Figure 3D. Additional file 4 summarizes threshold values from realtime RT-PCR for TR $\alpha 2$ across all tissues and ages (including the testes from 2 and 4 month animals) and shows parallel values for TR $\alpha 1$ for comparison. Two different downstream primers for TR $\alpha 2$ were used for most of these assays. In none of the assays was a product obtained consistent with splicing of TR 22 mRNA in opossum.

To test the efficiency and sensitivity of the TR $\alpha 2$ primers, realtime RT-PCR was carried out with a short synthetic DNA template matching the predicted amplicon sequence of opossum TR 22 mRNA. Serial dilutions of this template were assayed in the presence of a fixed amount of a negative cDNA preparation of $M$. domestica total RNA from cerebral cortex. The plot in Figure $3 \mathrm{E}$ indicates that these $\mathrm{TR} \alpha 2$-specific primers have a high efficiency, $>99 \%$ [39], and a sensitivity at $C_{\mathrm{T}}=33$ of less than 50 copies of TR $\alpha 2$ cDNA.

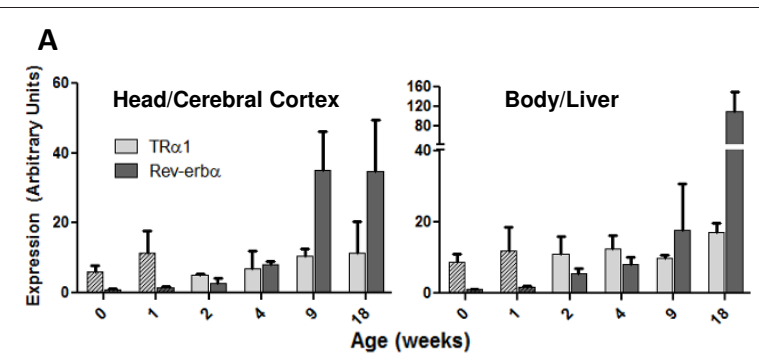

B

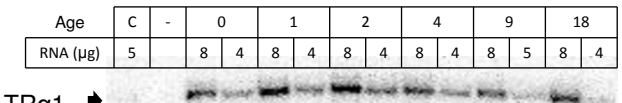

TRa1

TRa2

C
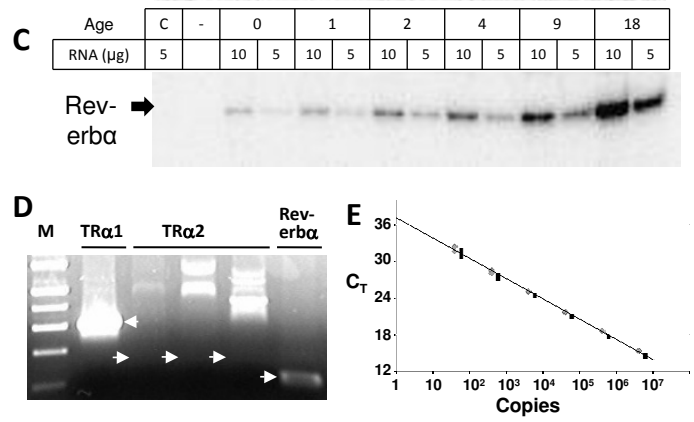

Figure 3 Expression of TR $\alpha 1$, Rev-erb $\alpha$ and TR $\alpha 2$ mRNAs in the opossum Monodelphis domestica. A. Expression of TR 1 and Reverbo in staged animals is shown for heads and bodies ( 0 days and one week of age, hatched bars) or cerebral cortex and liver (2-18 weeks, evenly shaded bars) based on realtime RT-PCR analysis. Results are averages from at least three animals with each assay performed in triplicate. Brackets indicate standard deviations. B and C. RNase protection assays of TR $\alpha(\mathbf{B})$ and Rev-erbo (C) expression in heads (0 days and one week) or cerebral cortex (2-18 weeks). Probes extend across exon 9A (TR $\alpha 1$ ) or the 5'ss of exon 6 (Rev-erbo) as indicated in Figure 1A, yielding protected bands of 156 or 137 nts for TRa 1 or Reverba, respectively. Control lanes include HEK 293 cell RNA which contains a low level of endogenous human RNA that cross-reacts with the opossum TR $\alpha$ probe (compare with a similar control with the opossum probe in Fig. 4D). Arrows indicate positions of the expected products. D. Electrophoretic analysis of realtime RT-PCR reactions illustrating absence of TRo 2 expression in M. domestica. Analysis of reactions run on same cDNA sample (day 0 heads) with arrows indicating positions of amplification products for TR 1 and Rev-erb $\alpha$ mRNAs and positions of product expected from correctly spliced TR $\alpha 2$ mRNA. Three replica reactions for TR $\alpha 2$ show a variety of artifactual products but no detectable product of the expected size. $\mathbf{E}$.

Amplification of a synthetic TR 2 template based on homologous sequences from opossum. Threshold cycle values $\left(C_{T}\right)$ are shown for serial dilution of test DNA in the presence of a constant amount of cDNA from day 0 heads (which has no detectable TR $\alpha 2$ ). Efficiencies of 99.4\% and $99.6 \%$ were calculated from two independent preparations of the gel-purified synthetic template.

Expression of TR $\alpha$ and Rev-erb $\alpha$ mRNAs was also measured by RNase protection assays on total RNA from the head (day 0 and week 1 animals) or cerebral cortex (2-18 week animals) as shown in Figure 3B. 
From the specific activity of the probe, the level of TR $\alpha 1$ mRNA was determined to vary between 0.3 and $0.7 \mathrm{amol} / \mu \mathrm{g}$ RNA ( $1 \mathrm{amol}=10^{-18}$ moles) with no clear stage-specific trend. On the other hand, Rev-erb $\alpha$ increased steadily from less than $0.1 \mathrm{amol} / \mu \mathrm{g}$ RNA in day 0 animals to about $1.0 \mathrm{amol} / \mathrm{ug}$ RNA in 18 week animals (Figure 3C), a trend paralleling the increase observed by realtime RT-PCR in cerebral cortex and several other tissues (Figure $3 \mathrm{~A}$ and additional file 3 ). TR $\alpha 1$ expression was assayed with a probe that extended across the 3' and 5' splice sites for exon 9A. The length of the protected fragment for TR $\alpha 1$ reveals efficient splicing of the former but not the latter site. In older opossums (9 and 18 weeks) a faint band corresponding in size to that expected for use of the 5'ss of TR $\alpha 2$ was observed. The presence of this band raises the possibility that an alternatively spliced product with a similar 5'ss to TR $\alpha 2$ is expressed in older animals. However, further efforts to identify such a product were unsuccessful.

\section{Requirements for splicing of $\mathrm{TR} \alpha 2$}

Although we found no evidence of TR $\alpha 2$ expression in $M$. domestica, the possibility remained that its expression is tightly restricted to some tissue, developmental stage or particular set of physiological conditions. To examine the intrinsic competency for splicing of conserved sequences corresponding to the 3'ss of exon 10 of TR $\alpha 2$, an opossum minigene was constructed based on the structure of a rat minigene that efficiently expressed TR $\alpha 2$ mRNA in transfection assays [32,40]. The construct consisted of exons 7-10 of TR $\alpha$, extending downstream to exon 7 of Rev-erb $\alpha$, with all the intron sequences except for a large deletion within intron 9 that eliminated the competing TR $\alpha 1$ polyadenylation site and much of the preceding 3' UTR (Figure 4A). This minigene was efficiently expressed in transient transfection assays in HEK 293 cells. RNA processing was assayed for both spliced (TR $\alpha 2$ ) and partially spliced ("unspliced" TR $\alpha 1$-like) RNA by conventional PCR (Figure 4B) and realtime RT-PCR (Figure 4C), as well as RNase protection assays (Figure 4D). Bands corresponding to spliced $T R \alpha 2$ were evident for the rat minigene (R-R) in all three assays. Real-time PCR and RNase protection assays yielded quantitative measures of TR $\alpha 2$ splicing relative to unspliced TR $\alpha 1$ of $64-77 \%$, consistent with earlier results for this minigene construct. Conventional PCR employing larger amplicons reveals a minor amount of a second spliced product corresponding to the minor spliced isoform, TR 33 (small arrow, Figure 4B). In contrast, no spliced product could be detected from the opossum minigene $(\mathrm{O}-\mathrm{O})$. The larger band evident in Figure 4B (lane O-O) corresponds to readthrough sequence, while the heterogeneous

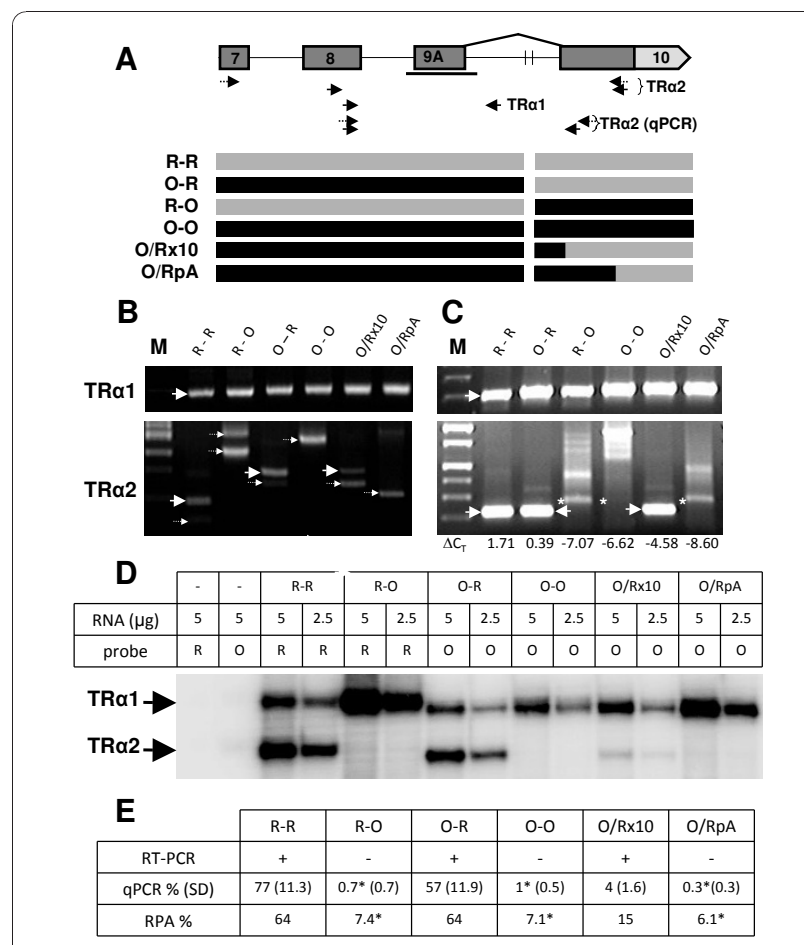

Figure 4 Splicing of chimeric TR $\alpha$ minigenes. A. Schematic showing intron-exon structure of TR $\alpha$ minigene. Light shading indicates the TRo2 $3^{\prime} U T R$. Vertical brackets indicate a $3.2 \mathrm{~kb}$ deletion in intron 9. Heavy horizontal line represents the exon 9A RNase protection probe (panel D). Arrows represent primers used for PCR (panels B and C) as described in Methods. Primer positions for TR $\alpha 2$ mRNA are indicated separately for rat (solid arrows) and opossum (dashed arrows); those for TR 1 are located at nearly identical positions. The composition of chimeric minigenes is indicated by horizontal bars aligned with structure at top: dark and light shading represents opossum and rat sequences, respectively. B, C. Electrophoretic analysis of conventional (B) or realtime (C) RT-PCR of RNA from transfected HEK 293 cells using primers indicated in Panel A. Large arrows indicate PCR products from correctly spliced TR 1 or TR 2 mRNAs. Dotted arrows indicate spliced products obtained from cryptic splicing within exon 10. Larger products seen with TRo2 primers from $\mathrm{R}-\mathrm{O}, \mathrm{O}-\mathrm{O}$ and O/RpA represent readthrough of unspliced or partially spliced RNAs, low levels of contaminating DNA (Panel B) or non-specific products (Panel C). $\Delta C_{T}$ values shown in Panel $C$ represent differences observed between threshold cycles $\left(C_{T}\right)$ for $T R \alpha 1$ and $T R \alpha 2\left(\Delta C_{T}=C_{T}^{T R \alpha 1}-C_{T}^{T R \alpha 2}\right)$ averaged over three replica assays from each of three independent experiments. $\mathbf{D}$. Analysis of minigene splicing by RNase protection assays using probes for exon 9A. E. Summary of results in panels B, C and D. Plus signs represent reactions where correct splicing of TR 2 was detected following sequencing of conventional PCR products. \% splicing was calculated from $\Delta C_{T}$ values (see Methods) with standard deviations given in parentheses. Asterisks represent possible false positives from non-specific RT-PCR products or high background in RNase protection assays.

bands in Figure 4C represent non-specific amplification products observed after 44 cycles of amplification. Close examination of the RNase protection assays (Figure 4D) revealed no bands corresponding to splicing of exon 9A. 
Figure 4E summarizes the results of each of the assays. A low level of residual background activity was routinely detected with RNase protection assays and real-time PCR yielding heterogenous amplification products, as indicated by asterisks in Figure 4E.

Given the efficiency of TR $\alpha 2$ splicing in the rat construct (R-R), the complete lack of expression of TR $\alpha 2$ splicing with the opossum minigene $(\mathrm{O}-\mathrm{O})$ was surprising. Both the 5' and 3' splice sites corresponding to $\mathrm{TR} \alpha 2$ are highly conserved in the rat and the opossum (Figure 2B and additional file 2), as are intronic sequences adjacent to 5' and 3' splice sites. Despite the high conservation of these sequences in marsupials and eutherians, the opossum TR $\alpha$ gene may lack cis-acting elements required for TR $\alpha 2$ expression [32,38,40]. To extend this analysis chimeric minigenes were constructed and assayed for their ability to express TR $\alpha 2$. One construct, O-R, consisting of opossum exons 7-9 upstream of the rat TR $\alpha 2$ 3' splice site and exon10, expressed $\mathrm{TR} \alpha 2$ transcripts at levels similar to the rat minigene (Figure 4B, C, and 4D). Sequencing of the RTPCR product obtained from transfected cells confirmed that this product was accurately spliced from the homologous 5' splice site in exon 9 of opossum to exon 10 of rat. In contrast, the reciprocal construct ( $\mathrm{R}-\mathrm{O})$ with rat sequences upstream (exons 7-9) and opossum sequences downstream (exon 10) was apparently unable to express spliced TR $\alpha 2$ mRNA. In all of the constructs tested, the upstream exons 7, 8 and 9 are efficiently and accurately spliced, but only in O-R, not O-O or R-O, is the downstream splice site corresponding to exon 10 efficiently used. These results demonstrate that sequences homologous to the TR $\alpha 25^{\prime}$ splice site in exon 9 of opossum are fully competent for splicing, while those homologous to the TR 22 3'ss in exon 10 are not.

To more precisely define cis-acting elements required for TR $\alpha 2$ splicing, two additional minigenes were tested. The first of these, designated $\mathrm{O} / \mathrm{Rx} 10$, was constructed from the $\mathrm{O}-\mathrm{R}$ chimera by replacing the rat sequence upstream of the TR $\alpha 2$ 3' splice site but downstream of intron 9 deletion with the opossum sequence present in the $\mathrm{O}-\mathrm{O}$ minigene. The other chimeric minigene, $\mathrm{O} /$ $\mathrm{RpA}$, was constructed by incorporating opossum sequences into the length of exon 8 , thus eliminating the rat 3'ss for TR $\alpha 2$ while retaining the rat TR $\alpha 2$ polyadenylation site (Figure 4A). When these chimeric minigenes were transfected into HEK 293 cells the efficiency of TR 2 splicing was greatly reduced or eliminated. Careful analysis revealed that the $\mathrm{O} / \mathrm{Rx} 10$ minigene expressed a small amount of correctly spliced chimeric TR $\alpha 2$ mRNA, as indicated by both RPA and RT-PCR assays, but with greatly reduced efficiency, strongly suggesting that opossum sequences in the intron upstream of exon 10 are incompatible with TR 22 splicing.
Post-run analysis of both $\mathrm{R}-\mathrm{O}$ and $\mathrm{O} / \mathrm{RpA}$ real-time products yielded a weak band in the region expected for correctly spliced product as indicated by the asterisks in Figure 4C. However, the difference between TR $\alpha 1$ and TR $\alpha 2 C_{T}$ values $\left(\Delta C_{T}\right.$ in Figure $\left.4 C\right)$ was comparable or less than that observed for the $\mathrm{O}-\mathrm{O}$ minigene. Correct splicing of these transcripts could not be confirmed by other assays. Cryptic splicing within the opossum sequence in $\mathrm{O} / \mathrm{RpA}, 60 \mathrm{nt}$ from the chimeric junction of opossum and rat sequence, was detected by sequencing a band obtained by conventional PCR. Conventional PCR also demonstrated that R-R, O-R and O/Rx10 all express a small amount of spliced TR $\alpha 3$, a minor variant of TR $\alpha 2$ that uses an alternative 3'ss 117 bp downstream of the TRa2 3'ss in exon 10 [41]. For R-R and $\mathrm{O}-\mathrm{R}$ this represents a minor product, slightly smaller than that for $\mathrm{TR} \alpha 2$. For $\mathrm{O} / \mathrm{Rx} 10$, however, this band is proportionately more intense, indicating a loss of specificity as well as a greatly reduced efficiency of TR $\alpha 2$ splicing for the O-Rx10 minigene.

The analysis described above strongly suggests that opossum sequences upstream of the 3'ss are incompatible with TR $\alpha 2$ splicing. The discrepancy between TR $\alpha 2$ splicing of $\mathrm{O}-\mathrm{R}$ and $\mathrm{O} / \mathrm{R} \times 10$ indicates that the $\mathrm{TR} \alpha$ gene of $M$. domestica lacks upstream cis-acting elements required for efficient splicing of TR $\alpha 2$. Furthermore, inclusion of the rat TR $\alpha 2$ polyadenylation site, which is not conserved in marsupial species (additional file 2), is insufficient to restore accurate and efficient splicing in chimeric constructs $\mathrm{O} / \mathrm{Rx} 10$ and $\mathrm{O} / \mathrm{RpA}$.

\section{Expression of endogenous and transfected mRNAs in PtK1 cells}

Analysis of the splicing of chimeric minigenes demonstrates that the opossum sequences homologous to the 3 'ss of TR $\alpha 2$ splicing are not used efficiently. This most likely reflects the lack of cis-acting elements in opossum that are necessary for TR $\alpha 2$ expression [38,40]. It is possible, however, that the failure of opossum tissues to express TR $\alpha 2$ reflects the presence or absence of a factor that specifically affects TR 2 processing. To test this possibility we examined the processing of the rat $\mathrm{TR} \alpha$ minigene in potoroo PtK1 cells. These cells, derived from kidney epithelium, endogenously expressed both TR $\alpha 1$ and Rev-erb $\alpha$, but not TR $\alpha 2$ (Figure 5A). PtK1 cells were then transfected with three previously characterized full-length rat minigenes [32]: a wildtype minigene extending uninterrupted from exon 7 through exon 10 of TR 22 (and further downstream to exon 2 of Rev-erb $\alpha$ ); a mutant with a single base replacement at the 5'ss of exon 9A $(+5 \mathrm{C} / \mathrm{G})$, which overexpresses $\mathrm{TR} \alpha 2$ mRNA; and a second mutant at that 5 'ss with substitution at the adjacent site $(+6 \mathrm{~T} / \mathrm{G})$, which results in a decrease in TR $\alpha 2$ mRNA. When transfected into PtK1 


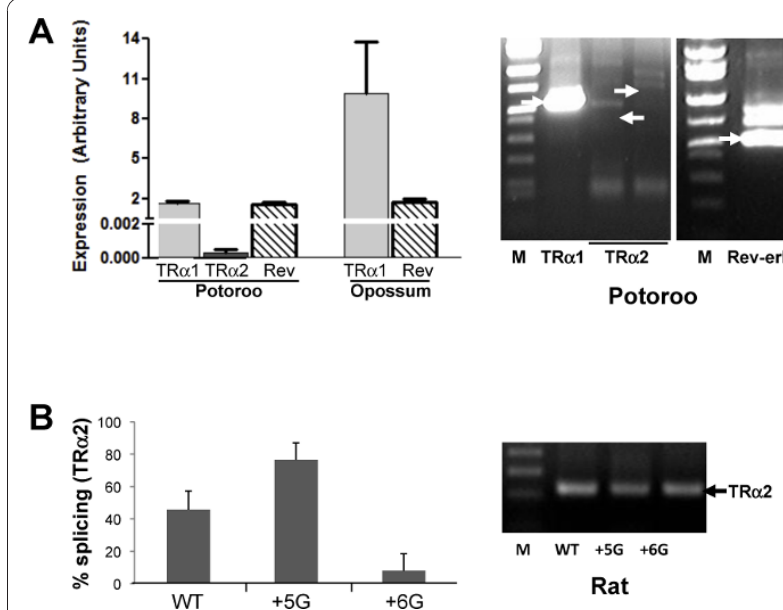

Figure 5 Expression of TR $\alpha$ and Rev-erb $\alpha$ in potoroo PtK1 cells A. Endogenous expression of TR $\alpha 1, T R \alpha 2$ and Rev-erb $\alpha$ mRNAs was assayed by realtime RT-PCR (left; average of 3 replicas) and conventional PCR (right). Expression of TR $\alpha 1$ and Rev-erb $\alpha$ mRNAs in the opossum, $M$. domestica (day 0 heads), was measured in a parallel by realtime RT-PCR for comparison. Arrows on photograph at right indicate positions of expected amplification products for each mRNA. Two different primer pairs were targeted against TR 2 , which was not observed. The predicted products for TRa 1 and Reverb $\alpha$ mRNAs were confirmed by sequencing. The Rev-erbo RT-PCR matches sequence obtained from PtK1 cell DNA (additional file 2). No TRo2 mRNA was observed either by realtime RT-PCR or two sets of primers located in exon 7 or 8 and exon 10. B. TRo 2 splicing of rat minigenes in PtK1 cells. Rat minigenes with full-length versions of exons 7-10 were expressed inPtK1 cells and assayed by realtime RT-PCR. Two previously characterized single-base point mutations in the 5'ss of exon 9A [32] were analyzed in parallel with wild-type and found to significantly overexpress $(+5 G)$ or underexpress $(+6 G)$ spliced TR $\alpha 2$ in comparison with wildtype $(p<0.05)$.

cells, each of these constructs expressed TR $\alpha 1$ and $\mathrm{TR} \alpha 2$ mRNAs at levels expected from previous expression studies in rodent and human cells (Figure 5B) [32]. These results demonstrate that marsupial cells expressing only endogenous TR $\alpha 1$ are fully capable of splicing rat $\mathrm{TR} \alpha 2$.

\section{Discussion}

Results of these studies show that TR $\alpha 1$ and Rev-erb $\alpha$ mRNAs are widely expressed in opossum in a manner similar to that in rodents, where both receptors are readily detectable in most tissues throughout development $[20,42,43]$, with expression peaking in post-natal, pre-weanling mice and rat. Since marsupials are born at a relatively early stage of development and mature more slowly than rats and mice, the ages used here correspond roughly to late pre-natal through post-weanling stages in rats. The striking increase in the expression of Rev-erb $\alpha$ in most tissues with increasing age is also consistent with that reported for rat [44]. However, the failure to detect expression of TR $\alpha 2$ in a broad range of tissues at ages ranging from day 0 newborns to 4 month-old young adults contrasts strongly with the co-expression of all three of these mRNAs from this locus in rats, mice and other mammals.

The expression of any one of these mRNAs, TR $\alpha 1$, TR $\alpha 2$ or Rev-erb $\alpha$, is almost always accompanied by expression of the other two, although the relative ratios vary widely $[20,21,33]$. Our analysis focused on the expression of these receptors in the central nervous system, as TR $\alpha 2$ mRNA is expressed at much higher levels than TR 1 in both cerebral cortex and cerebellum $[42,43]$. For example, in newborn rat brain TR $\alpha 2$ mRNA is more than 30-fold more abundant than TR $\alpha 1$ [42]. Furthermore, TR $\alpha 2$ expression in rats is several fold greater than TR $\alpha 1$ expression in brain, liver and kidney at all ages examined (day 15 embryos to adult) [42], a striking contrast to the total absence of TR $\alpha 2 \mathrm{mRNA}$ observed here in opossum and PtK1 cells.

\section{Conservation of sequences in TR $\alpha$ and Rev-erb $\alpha$}

The conservation of sequence spanning the 3' ends of $\mathrm{TR} \alpha 1$ and Rev-erb $\alpha$ has several features of interest with respect to the evolution of TR 22 and the antisense overlap with Rev-erba. The amino acid sequence encoded by the 3' exon of Rev-erba is nearly identical in marsupial and eutherian mammals (100\% identity in rat and opossum), suggesting that the coding sequence of Rev-erb $\alpha$ accommodated the evolution of its antisense overlap with TR $\alpha 2$ within its functional constraints as the coding sequence for TR $\alpha 2$ threaded through 67 (antisense) codons of Rev-erb $\alpha$ and into the final intron of the Reverb $\alpha$ gene. Interestingly, the one specific function ascribed to the unique $\mathrm{C}$-terminal sequence of $\mathrm{TR} \alpha 2$, that associated with phosphorylation of certain serine residues $[45,46]$, maps to positions in $\mathrm{TR} \alpha 2$ that are encoded antisense to the final intron of Rev-erb $\alpha$ and are therefore not constrained by requirements for Reverbo coding as shown in Figure 2A.

The region in which the 3' ends of TR $\alpha 1$ and Reverbo mRNAs converge is framed by exceptionally conserved sequences within the 3'UTR of each mRNA (additional file 2 ), suggesting the presence of numerous functional elements important for the expression and regulation of both nuclear receptor proteins. The apparent conservation of core splice site elements important for TR $\alpha 2$ expression is puzzling, given the apparent absence of TR $\alpha 2$ mRNA in marsupials, and raises the question of whether these elements correspond to TR $\alpha 2$ or have other functions. In particular, several features are consistent with conservation of the alternatively spliced TR $\alpha 2$-specific exon in marsupials: (1) conservation of the non-canonical AAG trinucleotide identical to that found in all known eutherian genomes at the 3' end 
of exon 9 for TR $\alpha 2$; (2) the conservation of adjacent sequences corresponding to the 5' end of exon 10; and (3) the conservation of the polypyrimidine tract that is an essential feature of the core sequence of the 3'ss. In fact, the marsupial polypyrimidine tract appears a better match to the mammalian consensus sequence than that found in rat: a $G$ at position -6 is replaced with $T$ in all four marsupials and a somewhat higher proportion of $\mathrm{T} / \mathrm{C}$ residues is present in the marsupial polypyrimidine tracts $[47,48]$.

However, other features of this region are consistent with the absence of TR $\alpha 2$ in opossum: (1) the open reading frame corresponding to the extended $\mathrm{C}$-terminus of TR $\alpha 2$ is not conserved in four marsupials except for the first 11 codons of TR $\alpha 2$ exon 10 in the opossums; (2) the bidirectional coding overlap with Rev-erbo present in all eutherian species is eliminated in both opossums; (3) the TR $\alpha 2$ ORF is disrupted in wallaby and potoroo by a frame-shift deletion adjacent to the presumptive splice site; (4) a conserved polyadenylation signal corresponding to exon 10 of $\mathrm{TR} \alpha 2$ is absent, and there is overall poor conservation of sequence within the final intron of Rev-erb $\alpha$ (additional file 2); and (5) there is poor conservation of intronic and exonic splicing enhancer sequences required for TR 2 splicing $[38,40]$. These include the SE $\alpha 2$ enhancer downstream of the coding sequence for TR 1 [40], an intronic splicing enhancer near the 3 ' splice site of exon 10 and a exonic enhancer located within the bidirectional coding sequence of exon 10 [38]. Taken together, these differences suggest that the conservation of the elements associated with TR $\alpha 2$ mRNA processing may reflect other functional requirements at this locus unrelated to $\mathrm{TR} \alpha 2$ expression.

\section{Splicing of TR 22 mRNA in chimeric minigenes}

Analysis of splicing of opossum and rat minigenes corroborated our finding that alternatively spliced $\mathrm{TR} \alpha 2$ mRNA is missing in marsupials. Most telling was the $\mathrm{O} /$ Rx10 construct, which includes the entire length of rat exon 10, identical to that in O-R, except for replacement of $180 \mathrm{bp}$ of rat sequence upstream of the TR $\alpha 23$ 'ss with $220 \mathrm{bp}$ of opossum sequence. The longer opossum sequence closely corresponds to a previously tested construct (ErbA $\triangle \mathrm{XP})$ which was spliced as efficiently as the shorter sequence [38]. The overall level of splicing of $\mathrm{O} /$ $\mathrm{Rx} 10$ was $<10 \%$ that of $\mathrm{O}-\mathrm{R}$ and the predominant spliced product corresponded to TR $\alpha 3$, a minor splice variant isoform, not TR $\alpha 2$, as shown by sequencing of RT-PCR products (Figure 4B). These experiments demonstrate that opossum sequences homologous to the TR $\alpha 2$-specific 3'ss are almost completely inactive in splicing transfected minigenes. In addition to the role of these intronic sequences in blocking TR 2 splicing, the opossum sequences also lacked a conserved polyadenylation signal hexanucleotide (CATAAA) that is conserved in all known TR $\alpha 2$ mRNAs. However, the inclusion of this element (together with much additional rat sequence) in the $\mathrm{O} / \mathrm{Rx} 10$ and $\mathrm{O} / \mathrm{RpA}$ minigenes was not sufficient to rescue efficient splicing.

\section{Evolution of TR $\alpha 2$ mRNA in mammals}

A number of studies suggest that the evolution of new alternative exons provides an important pathway for the creation of novel proteins and regulatory pathways in eukaryotic cells [49-52], reviewed in [53]. Given the prominence of TR $\alpha 2$ as an abundant isoform in eutherian mammals [42], its proposed role as a dominant negative modulator of thyroid hormone activity [19] and the possible regulatory implications of its overlap with Rev-erb $\alpha$ [33], the evolution and function of TR $\alpha 2$ in mammals are of particular interest.

Three distinct evolutionary scenarios or models may account for similarities and differences of this locus in marsupial species as summarized in Figure 6. The first scenario, in which TR $\alpha 2$ expression is restricted to the eutherian lineage, suggests that some features of the marsupial TR $\alpha / R e v-e r b \alpha$ locus are intermediate between those of eutherian mammals and non-mammalian vertebrates. For example, the poly(A) sites of TR $\alpha 1$ and Reverbo are nearly identically spaced in rat and opossum and much closer than in the amphibian Xenopus tropicalis, where they are more than $10 \mathrm{~kb}$ apart [38]. On the other hand, marsupials, like non-mammalian vertebrates, appear to lack an authentic TR $\alpha 2$ isoform. Also, the amino acid sequence of the marsupial TR $\alpha 1$ (additional file 1 Panel A) shows striking similarities to that of chicken. The opossum TR $\alpha 1$ amino acid sequence

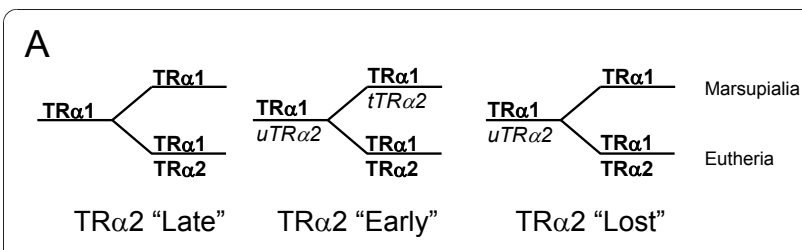

Figure 6 Models for the evolution of antisense exon 10 in TR $\alpha$ and expression of the TR $\alpha 2$ isoform. Three models are proposed for the evolution of the TR $\alpha 2$ isoform and its antisense overlap with Rev-erbo. In the first model (TR $\alpha 2$ "late"), alternatively spliced TRo2 mRNA evolved only after the divergence of marsupial and eutherian mammals so that TRo2 is unique to eutherian mammals. In the second model (TRo2 "early"), a functional but primitive version of TRo2 (UTR $\alpha 2$ ) evolved early in the course of mammalian evolution, but in marsupials the modern, truncated form of TRo2 (tTRo2) is expressed only at very low levels or its expression is temporally or spatially restricted. In the third model (TR 22 "lost"), a functional version of TR $\alpha 2$ (UTR $\alpha 2$ ) evolved very early in the common ancestor of marsupial and eutherian mammals, but this alternative isoform was lost at some later time in marsupial lineage. 
differs from chicken in only 22 positions as compared to 25 positions in rat (additional file 1 Panel A), despite a slightly greater similarity between the opossum and rat nucleotide coding sequences. In 20 of the 25 positions where opossum and rat TR $\alpha 1$ differ, the opossum sequence is identical to that of chicken. Most of these sites are also conserved in frog, a more distantly related vertebrate (result not shown). These observations suggest that the marsupial TR $\alpha$ locus has retained several characteristics reminiscent of non-mammalian vertebrates.

The second scenario, in which a truncated form of $\mathrm{TR} \alpha 2$ is expressed in some limited (though as yet undetected) fashion, also suggests that the marsupial locus may represent a stage intermediate between the more complex eutherian locus, with its extended antisense overlap with Rev-erb $\alpha$ and abundant expression of $\mathrm{TR} \alpha 2$, and the non-mammalian vertebrates, which entirely lack TR $\alpha 2$. Support for this model is found in the fact that many features characteristic of the marsupial TR $\alpha / R e v-e r b \alpha$ locus are associated with the creation of novel alternatively spliced exons, according to several recent studies [49-53]. These include inefficient splicing coupled with restricted or low levels of expression, as posited in the second model, and the absence of an extended open reading frame.

The third scenario, that TR $\alpha 2$ evolved early but was lost in the marsupial lineage, suggests that features characteristic of TR $\alpha 2$ that are shared by marsupial and eutherian mammals are vestiges of this loss. These vestigial features may have acquired other secondary functions within this locus. Although this scenario may appear overly complex and hence unlikely, careful analysis of nuclear receptor evolution throughout multiple metazoan phyla reveals that loss within a particular lineage is not at all uncommon [54]. Among approximately 25 nuclear receptor proteins that appear to have been present in the last common ancestor of vertebrate and bilaterian invertebrate species, a number of nuclear receptors, including both thyroid hormone receptor genes, are missing entirely from major groups of animals such as nematodes or arthropods while specific orthologs for both thyroid hormone receptors and Rev-erb are found in more distantly related animals, such as mollusks, tunicates and flatworms [55-57].

Although none of the three models can be definitively ruled out, on balance, the first scenario might be judged most likely. The failure to detect TR $\alpha 2$ expression in tissues and stages where it is abundantly expressed in eutherians, the poor efficiency of TR $\alpha 2$ minigene splicing, the absence of a discernible TR $\alpha 2$ polyadenylation signal element and differences between the presumptive coding sequence for $\mathrm{TR} \alpha 2$ in two marsupial orders weigh against the second model. The differences and similarities among the marsupial sequences within the 3 '
UTR of Rev-erba (Figure 2 and additional file 2), including strict conservation of 3' processing sites for $\mathrm{TR} \alpha 1$ and Rev-erb $\alpha$, seem most consistent with the first model, in which sequence conservation reflects regulatory requirements for these convergent mRNAs rather than vestiges of a once functional, alternatively spliced mRNA, as suggested in the third model.

If the first scenario is correct, apparent similarities between marsupials and eutherians in the region corresponding to the TR $\alpha 23^{\prime}$ ss and exon 10 must reflect other conserved functions. The first model thus suggests core elements of the TR $\alpha 2$ splice site were coopted (or "exapted") [58,59] during the evolution of TR $\alpha 2$. What, then, are the possible functions of these sequences? It is likely that they reflect the overlay of elements involved in regulating expression of $\mathrm{TR} \alpha$ and Rev-erb $\alpha$, as well as other possible roles. Accumulating evidence suggests that sequences at the 3' ends of genes play multiple roles in regulating gene expression. These include target sites for microRNA binding [60], sites for binding of proteins regulating transcription termination, 3' end processing, turnover and translation [61,62], and promoters for expression of non-coding transcripts that are often found within the 3' UTRs of transcripts $[1,3,7]$.

\section{Physiological correlates of nuclear receptor function}

The physiological role of TR $\alpha 2$ has remained elusive since its discovery more than two decades ago, despite numerous genetic and molecular investigations of its function [63-65]. Although many studies have focused on its role as a weak dominant negative competitor of TR $\alpha 1$ or TR $\beta$ isoforms [19,66-68], other studies have pointed to its phosphorylation-dependent RNA-binding activity and cytoplasmic localization $[46,69,70]$. These properties, along with the developmental regulation of its expression, suggest a role for TR $\alpha 2$ in developmental regulation of $\mathrm{T} 3$ activity $[71,72]$. The present study strongly indicates that its function is specific to the eutherian lineage, and thus may ultimately be resolved by comparative analysis of relevant aspects of marsupial and eutherian physiology.

The multiple roles ascribed to Rev-erb $\alpha$ and TR $\alpha 1$ in metabolic, circadian and developmental signaling [22,27,73-75] require a diversity of regulatory inputs that determine the expression and physiological activity of these receptors $[20,21]$. The evolution of the antisense overlap between TR $\alpha 2$ and Rev-erb $\alpha$ mRNAs in eutherian mammals is likely to be associated with additional mechanisms that affect the expression or activity of both receptors.

\section{Conclusions}

Analysis of the TR $\alpha / R e v-e r b \alpha$ locus in four marsupial species strongly suggests that the alternatively spliced 
TR $\alpha 2$ isoform, which is widely and abundantly expressed in all known eutherian mammals, is not present in marsupials. Three observations support this conclusion: first, we can find no evidence for $\mathrm{TR} \alpha 2$ expression in any of multiple tissues or developmental stages surveyed; second, the coding sequence specific to $\mathrm{TR} \alpha 2$ is severely truncated in opossums and completely altered in the wallaby and potoroo; and third, opossum sequences homologous to the 3'ss specific for TR $\alpha 2$ are utilized very inefficiently for splicing of chimeric minigenes. The antisense overlap between TR $\alpha 2$ and Reverb $\alpha$ mRNAs, which is tightly conserved in eutherian mammals, appears to have evolved within the constraints of the conserved C-terminal coding sequence of Rev-erb $\alpha$. These results suggest that comparative analysis of these genes in marsupials and eutherian mammals will provide further insight into the evolution, function and expression of TR $\alpha 2$ and the regulatory implications of its antisense overlap with Rev-erba.

\section{Methods}

\section{Tissues and cells}

Monodelphis domestica tissues were harvested from staged animals obtained from stocks maintained at the Southwest Foundation for Biomedical Research. The opossums were maintained under standard conditions for this species [76]. The Southwest Foundation for Biomedical Research is accredited by the Association for the Assessment and Accreditation of Animal Care, International. All procedures were approved by the Institutional Animal Care and Use Committee and conformed to the Public Health Service Policy on Humane Care and Use of Laboratory Animals. DNA was collected from animals at birth (0 days), 1, 2 and 4 weeks, 2 months (9 weeks) and 4 months (18 weeks). DNA from Didelphis virginiana was isolated from a purchased sample of brain tissue (Pel-Freez; Rogers, AR). Potorous tridactylus PtK1cells (CRL-6493) were obtained from ATCC (Manassas, VA) and passaged in Dulbeccos modified Eagles medium with 10\% fetal bovine serum.

\section{Nucleic acid sequencing and cloning}

DNA was sequenced from the overlap regions spanning the TR $\alpha$ and Rev-erb $\alpha$ genes of Didelphis virginiana and Potorous tridactylus following amplification of total DNA using primers complementary to conserved sites within exon 9 of TR $\alpha 1$ and exons 7 and 8 of Rev-erb $\alpha$. mRNA sequencing was similarly carried out with cDNA obtained by randomly primed reverse transcription of total RNA (Superscript II; Invitrogen) following homogenization of tissue in TRIzol according to manufacturer's instructions (Invitrogen). Amplified genomic products were also cloned into pGEM-T vector (Promega; Madison, WI) and subcloned into pErbA construct as previously described [40]. PCR amplifications were carried out with Taq polymerase (Promega). All primers were from Integrated DNA Technologies (Coral, IA)

Minigene plasmid constructs are based on the rat construct, pErbA $\triangle \mathrm{XE}$ ( $\mathrm{R}-\mathrm{R}$ in Figure 4$)$. Both the rat and possum constructs include all but the first $20 \mathrm{bp}$ of exon 7 , and all of exons $8,9 \mathrm{~A}$ and 10 [32,38]. In this plasmid intron 9 sequences are deleted from an XbaI site $490 \mathrm{bp}$ downstream of the 5'end of exon 9 in rat and a site $186 \mathrm{bp}$ upstream of the exon 10 3'ss. Sequences of both rat and opossum minigenes extend to a unique BstEII site in Rev-erbo exon 7 that is conserved in $M$. domestica. The opossum minigene, pErbA $(\mathrm{O}-\mathrm{O})$ ("O-O" in Figure 4) includes 620 bp of intron 9 upstream of the deletion and $226 \mathrm{nts}$ downstream following insertion of an XbaI site to facilitate swapping of rat and opossum sequences in construction of the chimeric plasmids pErbA(O-R) and pErbA(R-O) (Figure 4A). Chimeric plasmids $\mathrm{pErbA}(\mathrm{O} / \mathrm{RpA})$ and $\mathrm{pErbA}(\mathrm{O} /$ Rx10) were prepared by two-step recombinant PCR as previously described [38]. Wild-type plasmid pCMVErbAm and the corresponding 5'ss point mutants, $+5 \mathrm{C} /$ $\mathrm{G}$ and $+6 \mathrm{~T} / \mathrm{G}$, have been previously described [32] .

The following DNA and mRNA sequences (with NCBI accession) were analyzed using Vector NTI software (Invitrogen): $M$. domestica NW_001581875.1, XM_001370259, XM_001362861; Ratus novegicus NW_047339, NM_001017960, NM_031134, NM_001 113422; Gallus gallus NM_205313. The Macropus eugenii genomic sequence was assembled from the following files in the trace archives: ti:1070151041, ti:1437108730, ti:1378054157, ti:1582562684, ti:1623537866, ti:148431 7168, ti:1467742023, ti:1070151372.

The following sequences have been deposited in the GenBank: M. domestica TR $\alpha 1$ mRNA (HM149330), P. tridactylus TR 1 (HM149329), P. tridactylus NR1D1 (HM149328), P. tridactylus TR $\alpha 1 /$ Rev-erb $\alpha$ genomic sequence (HM149331), D. virginiana TR $\alpha 1 /$ Rev-erb $\alpha$ genomic sequence (HM149332). The M. eugenii TR $\alpha 1 /$ Rev-erb $\alpha$ genomic sequence has been deposited in the NCBI Bankit database (BK007078).

\section{Transfection assays and RNA analysis}

Plasmids were transfected into HEK 293 cells using calcium phosphate as described [32] and into PtK1 cells with Lipofectamine 2000 (Invitrogen). Total RNA was prepared from transfected cells with TRIzol $48 \mathrm{~h}$ posttransfection. RNA was assayed by RNase protection assays as previously described [32,33]. Riboprobes for rat TR $\alpha 1 / T R \alpha 2$ exon 9 and Rev-erb $\alpha$ exon 5 have been previously described [32]. Similar riboprobes were prepared for opossum Rev-erb $\alpha$ exon 5, TR $\alpha 1$ exons 9A, and TR $\alpha 1$ poly(A) site by in vitro transcription of PCR products cloned into pGEM-T vector (Promega) using 
primers described in (additional file 5). The riboprobe for opossum, unlike that for rat, extended upstream into intron 8 as well as downstream of the site homologous to exon 9A in TR $\alpha 2$ (Figure 4A). 3'RACE was carried out on RNA from liver and cerebral cortex from 4 month animals using gene specific primers for opossum Rev-erba. Direct sequencing of PCR products obtained with two gene-specific primers confirmed the presence of a major poly(A) site coincident with that found in rat, human and mouse in the EST database.

Quantitative realtime RT-PCR was carried out as follows. Total RNA was randomly primed and reverse transcribed with Superscript II. For expression assays with possum tissues, 4 ug of total RNA was used per reaction and the equivalent of $0.1 \mu \mathrm{g}$ of RNA product was used in a $25 \mu$ l reaction containing Bio-Rad SybrGreen Supermix and $150 \mathrm{nM}$ primers (additional file 5 ). RNA from transfected cells was similarly treated except less RNA was used. PCR values from opossum tissues were normalized to expression of opossum $\beta$ actin with primer to exons 5 and 6 . Realtime PCR assays were carried out on a MyiQ Realtime Thermocycler using IQ SyberGreen Supermix and analyzed according to the manufacturer's instructions (Bio-Rad Laboratories; Hercules, CA).

The following primers were used for amplification of chimeric gene products as shown in Figure 4C, with expected amplicon lengths (in base pairs) given in parentheses: for TR $\alpha 1$ in O-O, O-R, O/Rx10 and O/RpA: 1F/ 2R (290); for TR $\alpha 1$ in R-R and R-O: 15F/16R (291); (2) for $\mathrm{TR} \alpha 2$ in $\mathrm{O}-\mathrm{O}$ and $\mathrm{O} / \mathrm{RpA} 1 \mathrm{~F} / 6 \mathrm{R}$ (271); for TR $\alpha 2$ in $\mathrm{O}-\mathrm{R}$ and $\mathrm{O} / \mathrm{Rx} 10$ 1F/17R (222); for TR $\alpha 2$ in R-O 15F/6R (251); and for TR $\alpha 2$ in R-R 15F/17R (202). For conventional PCR shown in Figure 4B (40 cycles) the same primers for $\mathrm{TR} \alpha 1$ but for TR $\alpha 2$ longer amplicons were used: $\mathrm{O}-\mathrm{O}$ and O/RpA 20F/21R (722); O-R and O/Rx10 20F/23R (728); R-R 22F/23R (471); and R-O 22F/21R (464).

The efficiency of TR $\alpha 2$ primers was determined from the slope of the semilogarithmic plot of template concentration vs. $C_{\mathrm{T}}$ using the equation, efficiency $=\left[10^{\wedge}\right.$ $(-1 /$ slope $)]-1$ [39]. As a further test of primers used to probe for TR $\alpha 2$ expression, the "forward" TR $\alpha 2$ primer was paired with a "reverse" primer specific for TR $\alpha 1$, while the "reverse" TR $\alpha 2$ primers were paired with a "forward" primer specific to the 3' UTR of Rev-erbo. Each of these primer combinations efficiently amplified the expected mRNAs, supporting the conclusion that the failure to detect TR $\alpha 2$ mRNA does not reflect shortcomings of primer design (data not shown). Relative expression of $\mathrm{TR} \alpha 1$ and $\mathrm{TR} \alpha 2$ and percent splicing of TR $\alpha 2$ were calculated from realtime RT-PCR assuming $100 \%$ amplification efficiency. The significance of changes in expression was evaluated by Student's twosample unpooled $t$ test.

\section{Additional material}

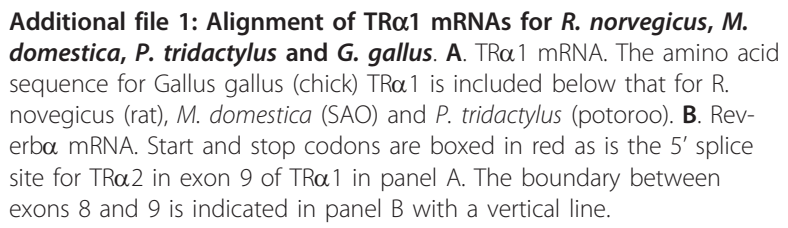

Additional file 2: Alignment of genomic sequence showing overlap region for rat, $M$. domestica (SAO), D. virginiana (NAO), $P$. tridactylus (potoroo) and $\boldsymbol{M}$. eugenii (wallaby). The alignment is annotated to show various features including polyadenylation sites and splice sites. The boundaries for subregions indicated in Figure 1B are also shown (vertical lines):. Red boxes indicate in-frame stop codons and polyadenylation signal sequences. Dotted red boxes in marsupial sequences show those stop codons inframe with the TR $\alpha 2$-specific splice site (as in Figure 2). Red arrows mark splice sites and polyadenylation sites.

Additional file 3: Expression of TR $\alpha 1$ and Rev-erb $\alpha$ in cerebellum, kidney, skeletal muscle and heart expression isolated from 2 to 18 week old opossums. Tissues from 2, 49 and 18 week old opossums ( $M$. domestica) were assayed for TR $\alpha 1$ and Rev-erb $\alpha$ expression as in Figure $3 \mathrm{~A}$. Results are averages of three animals, with each assay performed in triplicate. Brackets indicate standard deviations.

Additional file 4: Table showing realtime RT-PCR data illustrating absence of detectable TR $\alpha 2$ mRNA in opossum tissues. Uncorrected threshold values $\left(C_{T}\right.$ values) are shown for TR $\alpha 2$ mRNA in upper left of the box for each age and tissue. For comparison, values for TR 1 in parallel runs are shown the lower right of each box. Each value is the average of 3 replica determinations from a single run, with samples failing to reach the threshold arbitrarily set to 42 in determining the average. Boxes outlined in bold show runs where measurements for $\mathrm{TR} \alpha 1$ and TR $\alpha 2$ were carried out simultaneously. All samples were assayed for TR $\alpha 2$ with two different primer sets. Values shown without asterisks were measured with the primer pair evaluated in Figure 3E. Asterisks indicate measurements with an alternate TR $\alpha 2$ primer pair also used in Figure 3D. Replica values for TR 1 show little variation $(\mathrm{SD}<0.2$ for all but 4 measurements). $C_{T}$ values for TR $\alpha 2$ typically showed high values ( > 38) and/or substantial variation (SD > 1) characteristic of nonspecific products over a 44 cycle run.

Additional file 5: Table of primers used for PCR, DNA sequencing and plasmid constructions.

\section{Acknowledgements}

We would like to thank Janice MacRossin for assistance with collection of opossum tissues, Tessa Hoff for assistance with RNA sequencing and analysis, and David Durica (University of Oklahoma), Carol Munroe (Boston University) and Mitch Lazar (University of Pennsylvania) for their comments and advice on the manuscript. We are grateful for the support of National Institutes of Health (Grant R15 DK075418 to SHM) and the Robert J. Kleberg, Jr. and Helen C. Kleberg Foundation for support of the Monodelphis domestica breeding colony at the Southwest Foundation for Biomedical Research.

\section{Author details}

${ }^{1}$ Department of Biological Sciences, Marquette University, Milwaukee, WI, USA. ${ }^{2}$ Current address: Department of Pharmacology and Toxicology, Medical College of Wisconsin, Milwaukee, WI, USA. ${ }^{3}$ Current address: Department of Molecular Genetics and Cell Biology, University of Chicago, Chicago, IL, USA. ${ }^{4}$ Department of Genetics and Southwest National Primate 
Research Center, Southwest Foundation for Biomedical Research, San Antonio, TX, USA.

\section{Authors' contributions}

SHM and BCR initiated this study in consultation with JLV; BCR and MSB performed the experiments and SHM, MSB and BCR wrote the manuscript. All authors approved the final manuscript.

Received: 29 July 2010 Accepted: 10 December 2010 Published: 10 December 2010

\section{References}

1. Carninci P, Kasukawa T, Katayama S, Gough J, Frith MC, Maeda N, Oyama R, Ravasi T, Lenhard B, Wells C, Kodzius R, Shimokawa K, Bajic VB, Brenner SE Batalov S, Forrest AR, Zavolan M, Davis MJ, Wilming LG, Aidinis V, Allen JE, Ambesi-Impiombato A, Apweiler R, Aturaliya RN, Bailey TL, Bansal M, Baxter L, Beisel KW, Bersano $T$, Bono $H$, et al: The transcriptional landscape of the mammalian genome. Science 2005, 309(5740):1559-1563.

2. Jacquier $A$ : The complex eukaryotic transcriptome: unexpected pervasive transcription and novel small RNAs. Nat Rev Genet 2009, 10(12):833-844.

3. Kapranov P, Cheng J, Dike S, Nix DA, Duttagupta R, Willingham AT, Stadler PF, Hertel J, Hackermuller J, Hofacker IL, Bell I, Cheung E, Drenkow J, Dumais E, Patel S, Helt G, Ganesh M, Ghosh S, Piccolboni A, Sementchenko V, Tammana $H$, Gingeras TR: RNA maps reveal new RNA classes and a possible function for pervasive transcription. Science 2007, 316(5830):1484-1488

4. Kapranov P, Willingham AT, Gingeras TR: Genome-wide transcription and the implications for genomic organization. Nat Rev Genet 2007, 8(6):413-423

5. Katayama S, Tomaru Y, Kasukawa T, Waki K, Nakanishi M, Nakamura M, Nishida H, Yap CC, Suzuki M, Kawai J, Suzuki H, Carninci P, Hayashizaki Y, Wells C, Frith M, Ravasi T, Pang KC, Hallinan J, Mattick J, Hume DA, Lipovich L, Batalov S, Engström PG, Mizuno Y, Faghihi MA, Sandelin A Chalk AM, Mottagui-Tabar S, Liang Z, Lenhard B, et al: Antisense transcription in the mammalian transcriptome. Science 2005, 309(5740):1564-1566.

6. Wu JQ, Du J, Rozowsky J, Zhang Z, Urban AE, Euskirchen G, Weissman S, Gerstein M, Snyder M: Systematic analysis of transcribed loci in ENCODE regions using RACE sequencing reveals extensive transcription in the human genome. Genome Biol 2008, 9(1):R3.

7. He Y, Vogelstein B, Velculescu VE, Papadopoulos N, Kinzler KW: The antisense transcriptomes of human cells. Science 2008 322(5909):1855-1857.

8. Makalowska I, Lin CF, Makalowski W: Overlapping genes in vertebrate genomes. Comput Biol Chem 2005, 29(1):1-12.

9. Munroe $\mathrm{SH}$, Zhu J: Overlapping transcripts, double-stranded RNA and antisense regulation: a genomic perspective. Cell Mol Life Sci 2006 63(18):2102-2118.

10. Beiter T, Reich E, Williams RW, Simon P: Antisense transcription: a critical look in both directions. Cell Mol Life Sci 2009, 66(1):94-112.

11. Farnebo M: Wrap53, a novel regulator of p53. Cell Cycle 2009, 8(15):2343-2346

12. Houseley J, Rubbi L, Grunstein M, Tollervey D, Vogelauer M: A ncRNA modulates histone modification and mRNA induction in the yeast GAL gene cluster. Mol Cell 2008, 32(5):685-695.

13. Mahmoudi S, Henriksson S, Corcoran M, Mendez-Vidal C, Wiman KG, Farnebo M: Wrap53, a natural p53 antisense transcript required for p53 induction upon DNA damage. Mol Cell 2009, 33(4):462-471.

14. Lavorgna G, Dahary D, Lehner B, Sorek R, Sanderson CM, Casari G: In search of antisense. Trends Biochem Sci 2004, 29(2):88-94

15. Lazar MA, Hodin RA, Darling DS, Chin WW: A novel member of the thyroid/steroid hormone receptor family is encoded by the opposite strand of the rat c-erbA alpha transcriptional unit. Mol Cell Biol 1989, 9(3):1128-1136.

16. Miyajima N, Horiuchi R, Shibuya Y, Fukushige S, Matsubara K, Toyoshima K, Yamamoto T: Two erbA homologs encoding proteins with different T3 binding capacities are transcribed from opposite DNA strands of the same genetic locus. Cell 1989, 57(1):31-39.

17. Lazar MA: Thyroid hormone receptors: multiple forms, multiple possibilities. Endocr Rev 1993, 14(2):184-193.
18. Forrest D, Sjoberg M, Vennstrom B: Contrasting developmental and tissue-specific expression of alpha and beta thyroid hormone receptor genes. EMBO J 1990, 9(5):1519-1528.

19. Zhang J, Lazar MA: The mechanism of action of thyroid hormones. Annu Rev Physiol 2000, 62:439-466.

20. Bookout AL, Jeong Y, Downes M, Yu RT, Evans RM, Mangelsdorf DJ: Anatomical profiling of nuclear receptor expression reveals a hierarchical transcriptional network. Cell 2006, 126(4):789-799.

21. Yang X, Downes M, Yu RT, Bookout AL, He W, Straume M, Mangelsdorf DJ, Evans RM: Nuclear receptor expression links the circadian clock to metabolism. Cell 2006, 126(4):801-810.

22. Preitner N, Damiola F, Lopez-Molina L, Zakany J, Duboule D, Albrecht U, Schibler U: The orphan nuclear receptor REV-ERBalpha controls circadian transcription within the positive limb of the mammalian circadian oscillator. Cell 2002, 110(2):251-260

23. Pardee $\mathrm{Kl}, \mathrm{Xu} X$, Reinking J, Schuetz A, Dong A, Liu S, Zhang $\mathrm{R}$, Tiefenbach J, Lajoie G, Plotnikov AN, Botchkarev A, Krause HM, Edwards A: The structural basis of gas-responsive transcription by the human nuclear hormone receptor REV-ERBbeta. PLOS Biol 2009, 7(2):e43.

24. Raghuram S, Stayrook KR, Huang P, Rogers PM, Nosie AK, McClure DB, Burris LL, Khorasanizadeh S, Burris TP, Rastinejad F: Identification of heme as the ligand for the orphan nuclear receptors REV-ERBalpha and REVERBbeta. Nat Struct Mol Biol 2007, 14(12):1207-1213.

25. Rogers PM, Ying L, Burris TP: Relationship between circadian oscillations of Rev-erbalpha expression and intracellular levels of its ligand, heme. Biochem Biophys Res Commun 2008, 368(4):955-958.

26. Yin L, Wu N, Curtin JC, Qatanani M, Szwergold NR, Reid RA, Waitt GM, Parks DJ, Pearce KH, Wisely GB, Lazar MA: Rev-erbalpha, a heme sensor that coordinates metabolic and circadian pathways. Science 2007, 318(5857):1786-1789.

27. Wu N, Yin L, Hanniman EA, Joshi S, Lazar MA: Negative feedback maintenance of heme homeostasis by its receptor, Rev-erbalpha. Genes Dev 2009, 23(18):2201-2209.

28. Yin L, Wu N, Lazar MA: Nuclear receptor Rev-erbaa: a heme receptor that coordinates circadian rhythm and metabolism. Nucl Recept Signal 8:e001.

29. Alenghat T, Meyers K, Mullican SE, Leitner K, Adeniji-Adele A, Avila J, Bucan M, Ahima RS, Kaestner KH, Lazar MA: Nuclear receptor corepressor and histone deacetylase 3 govern circadian metabolic physiology. Nature 2008, 456(7224):997-1000.

30. Estall JL, Ruas JL, Choi CS, Laznik D, Badman M, Maratos-Flier E, Shulman Gl, Spiegelman BM: PGC-1a negatively regulates hepatic FGF21 expression by modulating the heme/Rev-Erba axis. Proc Natl Acad Sci USA 2009 106(52):22510-22515.

31. Burris TP: Nuclear hormone receptors for heme: REV-ERBa and REV-ERB $\beta$ are ligand-regulated components of the mammalian clock. Mol Endocrinol 2008, 22(7):1509-1520.

32. Hastings ML, Ingle HA, Lazar MA, Munroe SH: Post-transcriptional regulation of thyroid hormone receptor expression by cis-acting sequences and a naturally occurring antisense RNA. J Biol Chem 2000, 275(15):11507-11513

33. Hastings ML, Milcarek C, Martincic K, Peterson ML, Munroe SH: Expression of the thyroid hormone receptor gene, erbAalpha, in B lymphocytes: alternative mRNA processing is independent of differentiation but correlates with antisense RNA levels. Nucleic Acids Res 1997, 25(21):4296-4300.

34. Lazar MA, Hodin RA, Cardona G, Chin WW: Gene expression from the cerbA a/Rev-ErbAa genomic locus. Potential regulation of alternative splicing by opposite strand transcription. J Biol Chem 1990, 265(22):12859-12863.

35. Munroe $\mathrm{SH}$, Lazar MA: Inhibition of c-erbA mRNA splicing by a naturally occurring antisense RNA. J Biol Chem 1991, 266(33):22083-22086.

36. Mikkelsen TS, Wakefield MJ, Aken B, Amemiya CT, Chang JL, Duke S, Garber M, Gentles AJ, Goodstadt L, Heger A, Jurka J, Kamal M, Mauceli E, Searle SM, Sharpe T, Baker ML, Batzer MA, Benos PV, Belov K, Clamp M, Cook A, Cuff J, Das R, Davidow L, Deakin JE, Fazzari MJ, Glass JL, Grabherr M, Greally JM, Gu W, et al: Genome of the marsupial Monodelphis domestica reveals innovation in non-coding sequences. Nature 2007, 447(7141):167-177.

37. Samollow PB: The opossum genome: insights and opportunities from an alternative mammal. Genome Res 2008, 18(8):1199-1215. 
38. Salato VK, Rediske NW, Zhang C, Hastings ML, Munroe SH: An exonic splicing enhancer within a bidirectional coding sequence regulates splicing of an antisense mRNA. RNA Biology 2010, 7(2):179-190.

39. Wong ML, Medrano JF: Real-time PCR for mRNA quantitation. Biotechniques 2005, 39(1):75-85.

40. Hastings ML, Wilson CM, Munroe SH: A purine-rich intronic element enhances alternative splicing of thyroid hormone receptor mRNA. RNA 2001, 7(6):859-874.

41. Mitsuhashi T, Nikodem VM: Regulation of expression of the alternative mRNAs of the rat alpha-thyroid hormone receptor gene. J Biol Chem 1989, 264(15):8900-8904.

42. Keijzer R, Blommaart PJ, Labruyere WT, Vermeulen JL, Doulabi BZ, Bakker O, Tibboel D, Lamers WH: Expression of thyroid hormone receptors $A$ and $B$ in developing rat tissues; evidence for extensive posttranscriptional regulation. J Mol Endocrinol 2007, 38(5):523-535.

43. Strait KA, Schwartz HL, Perez-Castillo A, Oppenheimer JH: Relationship of cerbA mRNA content to tissue triiodothyronine nuclear binding capacity and function in developing and adult rats. J Biol Chem 1990, 265(18):10514-10521.

44. Jannini EA, Mitsuhashi T, Nikodem VM: Developmental expression of mRNAs from a rat C-erbA genomic locus. Biochem Biophys Res Commun 1992, 184(2):739-745

45. Katz D, Reginato MJ, Lazar MA: Functional regulation of thyroid hormone receptor variant TRa2 by phosphorylation. Mol Cell Biol 1995, 15(5):2341-2348

46. Xu B, Koenig RJ: An RNA-binding domain in the thyroid hormone receptor enhances transcriptional activation. J Biol Chem 2004, 279(32):33051-33056.

47. Burge CB, Tuschl T, Sharp PA: Splicing of precursors to mRNAs by the spliceosomes. In The RNA World.. second edition. Edited by: Gesteland RF, Cech TR, Atkins JF. Cold Spring Harbor, NY: Cold Spring Harbor Press; 1999:525-560

48. Sheth N, Roca X, Hastings ML, Roeder T, Krainer AR, Sachidanandam R: Comprehensive splice-site analysis using comparative genomics. Nucleic Acids Res 2006, 34(14):3955-3967.

49. Xing $Y$, Lee C: Evidence of functional selection pressure for alternative splicing events that accelerate evolution of protein subsequences. Proc Natl Acad Sci USA 2005, 102(38):13526-13531.

50. Modrek $B$, Lee $\mathrm{CJ}$ : Alternative splicing in the human, mouse and rat genomes is associated with an increased frequency of exon creation and/or loss. Nat Genet 2003, 34(2):177-180.

51. Nurtdinov RN, Mironov AA, Gelfand MS: Rodent-specific alternative exons are more frequent in rapidly evolving genes and in paralogs. BMC Evol Biol 2009, 9:142.

52. Zhang $\mathrm{XH}$, Chasin LA: Comparison of multiple vertebrate genomes reveals the birth and evolution of human exons. Proc Natl Acad Sci USA 2006, 103(36):13427-13432.

53. Xing $Y$, Lee $C$ : Alternative splicing and RNA selection pressureevolutionary consequences for eukaryotic genomes. Nat Rev Genet 2006, 7(7):499-509.

54. Bertrand S, Brunet FG, Escriva H, Parmentier G, Laudet V, RobinsonRechavi M: Evolutionary genomics of nuclear receptors: from twenty-five ancestral genes to derived endocrine systems. Mol Biol Evol 2004, 21(10):1923-1937.

55. Paris M, Brunet F, Markov GV, Schubert M, Laudet V: The amphioxus genome enlightens the evolution of the thyroid hormone signaling pathway. Dev Genes Evol 2008, 218(11-12):667-680

56. Paris M, Escriva H, Schubert M, Brunet F, Brtko J, Ciesielski F, Roecklin D, Vivat-Hannah V, Jamin EL, Cravedi JP, Scanlan TS, Renaud JP, Holland ND, Laudet $\mathrm{V}$ : Amphioxus postembryonic development reveals the homology of chordate metamorphosis. Curr Biol 2008, 18(11):825-830.

57. Wu W, Niles EG, LoVerde PT: Thyroid hormone receptor orthologues from invertebrate species with emphasis on Schistosoma mansoni. BMC Evol Biol 2007, 7:150.

58. Brosius J, Gould SJ: On "genomenclature": a comprehensive (and respectful) taxonomy for pseudogenes and other "junk DNA". Proc Natl Acad Sci USA 1992, 89(22):10706-10710.

59. Makalowska I, Lin CF, Hernandez K: Birth and death of gene overlaps in vertebrates. BMC Evol Biol 2007, 7:193.

60. Bartel DP: MicroRNAs: target recognition and regulatory functions. Cell 2009, 136(2):215-233
61. Moore MJ, Proudfoot NJ: Pre-mRNA processing reaches back to transcription and ahead to translation. Cell 2009, 136(4):688-700.

62. Licatalosi DD, Darnell RB: RNA processing and its regulation: global insights into biological networks. Nat Rev Genet 11(1):75-87.

63. Izumo S, Mahdavi V: Thyroid hormone receptor alpha isoforms generated by alternative splicing differentially activate myosin $\mathrm{HC}$ gene transcription. Nature 1988, 334(6182):539-542.

64. Mitsuhashi T, Tennyson GE, Nikodem VM: Alternative splicing generates messages encoding rat c-erbA proteins that do not bind thyroid hormone. Proc Natl Acad Sci USA 1988, 85(16):5804-5808.

65. Flamant F, Samarut J: Thyroid hormone receptors: lessons from knockout and knock-in mutant mice. Trends Endocrinol Metab 2003, 14(2):85-90.

66. Tagami T, Kopp P, Johnson W, Arseven OK, Jameson JL: The thyroid hormone receptor variant alpha2 is a weak antagonist because it is deficient in interactions with nuclear receptor corepressors. Endocrinology 1998, 139(5):2535-2544.

67. Reginato MJ, Zhang J, Lazar MA: DNA-independent and DNA-dependent mechanisms regulate the differential heterodimerization of the isoforms of the thyroid hormone receptor with retinoid $\times$ receptor. J Biol Chem 1996, 271(45):28199-28205

68. Yang YZ, Burgos-Trinidad M, Wu Y, Koenig RJ: Thyroid hormone receptor variant alpha2. Role of the ninth heptad in dna binding, heterodimerization with retinoid $\times$ receptors, and dominant negative activity. J Biol Chem 1996, 271(45):28235-28242.

69. Xu B, Koenig RJ: Regulation of thyroid hormone receptor alpha2 RNA binding and subcellular localization by phosphorylation. Mol Cell Endocrinol 2005, 245(1-2):147-157.

70. Colley SM, Leedman PJ: SRA and its binding partners: an expanding role for RNA-binding coregulators in nuclear receptor-mediated gene regulation. Crit Rev Biochem Mol Biol 2009, 44(1):25-33.

71. Hodin RA, Meng S, Chamberlain SM: Thyroid hormone responsiveness is developmentally regulated in the rat small intestine: a possible role for the alpha-2 receptor variant. Endocrinology 1994, 135(2):564-568.

72. Wills KN, Zhang XK, Pfahl M: Coordinate expression of functionally distinct thyroid hormone receptor alpha isoforms during neonatal brain development. Mol Endocrinol 1991, 5(8):1109-1119.

73. Gatfield D, Le Martelot G, Vejnar CE, Gerlach D, Schaad O, Fleury-Olela F, Ruskeepaa AL, Oresic M, Esau CC, Zdobnov EM, Schibler U: Integration of microRNA miR-122 in hepatic circadian gene expression. Genes Dev 2009, 23(11):1313-1326.

74. Le Martelot G, Claudel T, Gatfield D, Schaad O, Kornmann B, Sasso GL, Moschetta A, Schibler U: REV-ERBalpha participates in circadian SREBP signaling and bile acid homeostasis. PLOS Biol 2009, 7(9):e1000181.

75. Wang J, Lazar MA: Bifunctional role of Rev-erbalpha in adipocyte differentiation. Mol Cell Biol 2008, 28(7):2213-2220.

76. VandeBerg JL, Williams-Blangero S: The laboratory opossum. In The UFAW Handbook on the Care and Use of Laboratory and Other Research Animals. Volume Chapter 19.. 8 edition. Edited by: Hulbrecht R, Kirkwood J. West Sussex: Wiley-Blackwell; 2010:246-261.

doi:10.1186/1471-2199-11-97

Cite this article as: Rindfleisch et al:: Structure and expression of two nuclear receptor genes in marsupials: insights into the evolution of the antisense overlap between the $\alpha$-thyroid hormone receptor and Reverba. BMC Molecular Biology 2010 11:97.

\section{Submit your next manuscript to BioMed Central and take full advantage of:}

- Convenient online submission

- Thorough peer review

- No space constraints or color figure charges

- Immediate publication on acceptance

- Inclusion in PubMed, CAS, Scopus and Google Scholar

- Research which is freely available for redistribution 